\title{
Response of Needle-and-thread and Western Wheatgrass to Defoliation by Grasshoppers
}

\author{
WAYNE H. BURLESON AND GEORGE B. HEWITT
}

\section{Abstract}

Field and greenhouse studies were conducted to measure changes in plant growth resulting from grasshopper defoliation. All data indicated that as grasshopper grazing intensity on needleand-thread grass increased, total root weight decreased. A greenhouse study with western wheatgrass showed that heavy grazing (80\% removal of top growth) for a 16-day period reduced top growth $82 \%$, root growth $85 \%$, crown growth $81 \%$, rhizome growth $100 \%$, and depth of root penetration $49 \%$. Field observations indicated that most grasshopper defoliation of needle-andthread grass and western wheatgrass occurs after seasonal growth has been completed.

Most plants that benefit mankind also provide food and shelter for many species of insects. Grasshoppers have long been considered the major pests inhabiting rangeland throughout the western United States and Canada, and since they feed on most forage plants, especially grasses, they have the potential to increase to outbreak numbers in any year and at many locations (Hewitt 1977). Species distribution, biology, food and habitat preferences, and economic importance have been determined for most grasshopper species inhabiting western rangeland. However, very little is known about the effects of insect defoliation. The effects of clipping or grazing plants with livestock have been studied for several plant species, but the effects of grasshopper grazing have never been adequately documented.

Grasshoppers lower the production of rangeland forage by defoliating plants, part of which is consumed and part falls to the ground as litter. The effect of this grazing or defoliation upon plant development depends upon the intensity, frequency, selectivity, and season of use. In this study, we measured changes in plant growth resulting from grasshopper defoliation. The development, vigor, and survival of needle-and-thread grass (Stipa comata Trin. \& Rupr.) and western wheatgrass (Agropyron smithii Rydb.) were measured under different grasshopper density infestations in both the greenhouse and the field.

\section{Methods and Materials}

\section{Study Area}

The study area was located $12.8 \mathrm{~km}$ northeast of Three Forks, MT., in Broadwater County. A 16-ha experimental site was excluded from livestock grazing in 1973. This site had been plowed approximately 30 years earlier and later abandoned. The area is located on an upland bench with a $2 \%$ slope and a southeast exposure. The climate is cool and semiarid with an annual average precipitation of $30.5 \mathrm{~cm}$, most of which occurs during the spring months.

The soil type is classified as a Brocko series in the mixed family Borollic Calciorthid. The texture throughout the profile ranges

\footnotetext{
Authors are with the Rangeland Insect Laboratory, Agr. Res., U.S. Dep. Agr. Agr., Res. Serv., Bozeman, Montana 59717. Burleson's present adress is U.S. Dep. Agr., Wallowa Whitman National Forest, Hells Canyon National Recreation Area, P.O. Box 832, Riggins, Idaho 83549.

Manuscript received June $12,1980$.
}

from very fine sandy loam to silt loam with 8 to $18 \%$ noncarbonate clay and 1 to $14 \%$ fine sand to coarser particles. Brocko soils are formed from eolian material that has been deposited over older river terraces.

\section{Needie-and-thread Grass-Greenhouse Study}

Plants about $5 \mathrm{~cm}$ in basal diameter were removed from the study area in November, 1973; the tops were trimmed to $2.5 \mathrm{~cm}$ and the roots to $8 \mathrm{~cm}$. The plants were then stored outdoors in Bozeman, MT., until January 16, 1974, when 12 plants were placed one each in root boxes $(60 \times 29 \times 23 \mathrm{~cm})$ filled with a soil mixture consisting of 75 parts washed sand and 25 parts peat. The root boxes had sloping, removable glass fronts.

The greenhouse air temperature ranged from $25^{\circ}$ to $30^{\circ} \mathrm{C}$; soil temperature at a depth of $10 \mathrm{~cm}$ ranged from $18^{\circ}$ to $26^{\circ} \mathrm{C}$. The photoperiod consisted of natural day length, with the light diffused through transparent, corrugated, fiberglass paneling.

At the initiation of the tests ( 72 days of plant growth) 3rd-instar migratory grasshoppers, Melanoplus sanguinipes (F.), were randomly placed in four replicated cages at densities of 12 (heavy grazing), three (light grazing), and zero (control) grasshoppers per cage. The grasshopper density was periodically adjusted by removal or addition of grasshoppers of equal age to maintain equal defoliation levels within each treatment.

To determine the effects of grasshopper grazing on new growth, 12 additional plants were started in root boxes 1 week before grasshopper introduction onto the 72-day-old plants. These 12 plants were randomly divided into three similar treatments and infested at densities of 3,1, and 0 grasshoppers per plant in order to duplicate the previously mentioned grazing intensities. Root growth was not measured in this phase of the study.

On May 16, 1974, the test was ended and the plants were washed from the root boxes; divided into root, crowns, and top growth; oven-dried at $60^{\circ} \mathrm{C}$; and weighed. In this phase of the study, crown consisted of the basal area of the culm through $8 \mathrm{~cm}$ of roots.

\section{Needle-and-thread Grass-Field Study}

Needle-and-thread grass plants grazed by grasshoppers were compared to ungrazed plants at the Three Forks site. Ten somewhat isolated plants of approximately the same size (basal diameter approximately $5 \mathrm{~cm}$ ) were selected and excavated on June 20,1974 . The root system was cut $8 \mathrm{~cm}$ below the surface level, and the flag leaf and sheath containing the inflorescence were removed. These plants were then replanted in their original spots and enclosed in metal cages (Mazuranich 1975). Five randomly selected caged plants were then each infested with six 3rd- to 4th-instar bigheaded grasshoppers, (Aulocara elliotti Thomas). The five remaining caged plants were used as controls. During this test, the grasshoppers were maintained at a density of at least two grasshoppers per cage.

Another group of ten needle-and-thread grass plants were similarly selected although not excavated. Five of these plants were caged and infested with $A$. elliotti at the same density as the excavated plants.

The test ended after 48 days, at which time all grasshoppers were dead. The plants were then excavated in approximately equal size 
blocks $(15 \times 15 \times 30 \mathrm{~cm})$ and brought into the laboratory. The plants were then presoaked, washed, and separated into tops, crowns, and roots, oven-dried for 24 hours, and weighed.

\section{Western Wheatgrass-Greenhouse Study}

Western wheatgrass (A. smithii var. rosana) seeds were germinated on March 1, 1975. Five-day old seedlings were labeled "day one" in the experiment. On day two, 100 seedlings of uniform size and vigor were transferred into 25 of the glass-faced root boxes. The four seedlings per box were placed $1 \mathrm{~cm}$ from the slanting glass.

The soil used in this experiment, 1/2 washed sand and $1 / 2$ Bozeman silt loam, was mixed by hand. The loam was sterilized by steam for 24 hours. The root boxes were laid on their sides and filled with the mixed soil. Sifted soil, placed next to the glass, formed the top layer of each root box. All root boxes were then heavily watered and left until the soil settled on the glass.

On day 31 , the 25 root boxes were randomly divided into five treatments, each having five replications in a randomized complete block design. The five treatments were:

1. A one-time clipping $2.5 \mathrm{~cm}$ above the surface to remove $90 \%$ of the top growth;

2. Heavy grazing by grasshoppers $(80 \%$ removal by weight of top growth);

3. Moderate grazing by grasshoppers ( $50 \%$ removal);

4. Light grazing by grasshoppers ( $20 \%$ removal);

5. Ungrazed.

The grazing levels were maintained for a period of 16 days by the two-striped grasshopper Melanoplus bivittatus (Say). Grasshopper densities were periodically adjusted to establish equal levels of defoliation within a treatment. The grazing treatment ended on day 48 , after which the plants continued to grow until day 93 .

Daily root growth measurements were made at the start of the test and during the treatment period. The number of tillers and shoots from rhizomes was recorded for each root box. On day 93 the plants were separated into tops, crowns, roots, and rhizomes, oven-dried at $60^{\circ} \mathrm{C}$, and then weighed. The crown consisted of the immediate basal portion of the culm and small $(5 \mathrm{~mm})$ portions of the roots.

\section{Plant and Grasshopper Growth Curves}

Grasshopper development was related to plant development under field conditions. Four glass panes were buried at 45 degree angles in the field on May 2, 1975. Soil was removed from one side of the glass so plant growth on the opposite side could be observed. Sifted soil was placed next to the glass on two of the panes and a seedling of western wheatgrass was planted behind one pane and a needle-and-thread seedling behind the other. The other two panes were buried near and partially under natural occurring plants the soil partially removed from one side to allow for observations.

Root growth and plant phenology was recorded bi-weekly from May to September. Grasshoppers were collected with a sweep net each week, stored in a freezer, and later identified by specics and developmental stage.

\section{Results}

\section{Needle-and-thread Grass Defoliation}

The two defoliation treatments of the older group of plants tested in the greenhouse were grazed for $\mathbf{4 8}$ days by grasshoppers. Approximately 50 and $70 \%$ of the top growth by weight was removed by moderate and heavy grazing, respectively, and root growth was reduced about $50 \%$ at both intensities as compared to the ungrazed plants (Table 1). It appears that the crown weights nearly doubled under heavy grazing; however, this could be due to an error in selection of plants for the various treatments. It is possible that plants with large crowns were placed in the heavily grazed treatment. The crown weights reported in the field tests are probably more accurate since the crowns of the grazed plants weighed less than the ungrazed plants in both excavated and nonexcavated plants. The moderately grazed crown weights did
Table 1. Mean dry weights (g) of needle-and-thread grass as related to growth under indicated treatments, Bozeman, MT. 1974.

\begin{tabular}{|c|c|c|c|}
\hline \multicolumn{4}{|c|}{ Greenhouse tests } \\
\hline \multirow[b]{2}{*}{ Plant part } & \multicolumn{3}{|c|}{ Treatment } \\
\hline & Ungrazed & $\begin{array}{l}\text { Moderately } \\
\text { grazed }\end{array}$ & $\begin{array}{l}\text { Heavily } \\
\text { grazed }\end{array}$ \\
\hline $\begin{array}{l}\text { Top' } \\
\text { Roots } \\
\text { Crown }^{2}\end{array}$ & $\begin{array}{l}1.72 \mathrm{a} \\
1.62 \\
6.26\end{array}$ & $\begin{array}{c}0.88 \mathrm{~b} \\
.89 \\
5.83\end{array}$ & $\begin{array}{r}0.51 \mathrm{c} \\
.82 \\
10.40\end{array}$ \\
\hline Crown $^{2}$ & \multicolumn{3}{|c|}{$\begin{array}{c}\text { Field tests } \\
\text { Plant pre-excavated }\end{array}$} \\
\hline Plant part & Ung & & Grazed \\
\hline $\begin{array}{l}\text { Top }{ }^{3} \\
\text { Roots } \\
\text { Crown }\end{array}$ & & & $\begin{array}{c}0.24 \\
1.08 \\
9.42\end{array}$ \\
\hline Crown & \multicolumn{3}{|c|}{ Plants not excavated } \\
\hline $\begin{array}{l}\text { Top } \\
\text { Roots } \\
\text { Crown }\end{array}$ & & & $\begin{array}{l}0.28 \\
1.60 \\
7.47\end{array}$ \\
\hline
\end{tabular}

1 Means followed by the same letter are not significantly different at the .05 level. ${ }^{2}$ No significant difference between means at the .05 level.

${ }^{3}$ Means differed significantly at the .01 level.

${ }^{4}$ Means differed significantly at the .05 level.

not differ significantly from the ungrazed crown weights.

Defoliation by grasshopper grazing on the seedlings (green-up phase) produced $100 \%$ plant mortality. New plant material could not be produced fast enough to compensate for grasshopper feeding. Results indicated that more than 1 week of plant growth is needed to withstand the stress of grasshopper grazing at the grasshopper densities tested.

The field test with needle-and-thread grass ended August 6, 1974, 48 days after the initial infestation, at which time all grasshoppers in the cages were dead. Grasshoppers fed on the plants between the time of inflorescence and seed shatter, by which time the grasshoppers had removed 83 and $88 \%$ (by weight) of the top growth of pre-excavated and nonexcavated plants, respectively (Table 1).

Roots of the grazed pre-excavated plants weighed $63 \%$ less than roots of ungrazed pre-excavated plants. The weight of roots of the nonexcavated plants was reduced $38 \%$ by grazing (Table 1 ).

The difference in weight between percentage root reduction of the pre-excavated and nonexcavated plants is probably a result of excavation of the plants before the grazing period. The root system under the nonexcavated plants included both old and new active roots. Crown weights were not significantly affected by grasshopper defoliation.

\section{Western Wheatgrass Defoliation}

In the greenhouse test, the grasshoppers removed 20,50 , and $80 \%$ (ocular estimate) of the top growth of seedlings as compared to that of ungrazed plants in light, moderate, and heavy grazing, respectively. The plants were harvested and weighed 46 days after grazing had ended. This particular time period was necessary to allow plants to recover from the effects of defoliation.

Top, root, crown, and rhizome regrowth and depth of root penetration response of western wheatgrass to defoliation is shown in Table 2 . The one time clipping ( $90 \%$ removal) was essentially equal to the moderately grazed treatment ( $50 \%$ continuous removal) in relation to the dry weights of all plant parts except rhizomes. For all criteria, dry weight was inversely proportional to grazing pessure. The heavily grazed treatment reduced top growth $82 \%$, root growth $85 \%$, crown growth $81 \%$, rhizome growth $100 \%$, and depth of root penetration $49 \%$.

Root penetration for all five treatments from days 28 through 55 is shown in Figure 1. The grazing period lasted from day 31 
Table 2. Mean dry weight (g) and root penetration (cm) of western wheatgrass as related to regrowth under the indicated treatments, Bozeman, Mon., 1974.

\begin{tabular}{|c|c|c|c|c|c|}
\hline \multirow[b]{2}{*}{$\begin{array}{l}\text { Plant } \\
\text { part }\end{array}$} & \multicolumn{5}{|c|}{ Treatment } \\
\hline & Ungrazed & $\begin{array}{l}\text { Lightly } \\
\text { grazed }\end{array}$ & Clipping & $\begin{array}{l}\text { Moderately } \\
\text { grazed }\end{array}$ & $\begin{array}{l}\text { Heavily } \\
\text { grazed }\end{array}$ \\
\hline \multirow[t]{3}{*}{$\begin{array}{l}\text { Top' } \\
\text { Roots' } \\
\text { Crown' } \\
\text { Rhizomes }\end{array}$} & $\begin{array}{l}0.749 \mathrm{a} \\
1.382 \mathrm{a} \\
.072 \mathrm{a} \\
.026\end{array}$ & $\begin{array}{l}0.609 \mathrm{ab} \\
1.116 \mathrm{a} \\
.059 \mathrm{a} \\
.014\end{array}$ & $\begin{array}{l}0.440 \mathrm{bc} \\
.551 \mathrm{bc} \\
.037 \mathrm{~b} \\
.015\end{array}$ & $\begin{array}{l}0.367 \mathrm{c} \\
.594 \mathrm{~b} \\
.037 \mathrm{~b} \\
.003\end{array}$ & $\begin{array}{l}0.133 \mathrm{~d} \\
.210 \mathrm{c} \\
.014 \mathrm{c} \\
.000\end{array}$ \\
\hline & \multicolumn{4}{|c|}{ Maximum depth of root penetration } & \\
\hline & 53.80 & 54.76 & 39.90 & 42.06 & 27.70 \\
\hline
\end{tabular}

Means followed by the same letter are not significantly different at the .05 level.

through day 47. The clipping treatment stopped all root growth for a period of 5 days, during which time the rate of top growth of the clipped plants increased compared to that of the ungrazed plants. By the end of the testing period on day 93, average heights of clipped and ungrazed plants were equal.

The grazing treatments did not have the immediate effect as in the clipping treatment, but as the defoliation intensity increased with time and the grasshoppers increased in size, daily root elongation gradually decreased. Root elongation nearly stopped on day 42 under the heavy grazing treatment. It is possible that if heavy grazing had continued, the western wheatgrass plants would have died. Plants in the lightly grazed treatment showed a root growth rate similar to those in the ungrazed treatment. The moderate grazing and clipping treatments were similar in that root elongation increased only slightly after day $\mathbf{4 4}$ (Fig. 1). Results indicate that heavy grazing by grasshoppers can be most detrimental to the roots.

The mean number of new shoots produced by western wheatgrass in response to the five treatments was a follows: light grazing 11.0 , ungrazed 10.4 , clipping 6.8 , moderate grazing 4.4 , and heavy grazing 0.0. Differences were not significant between the ungrazed, lightly grazed, and clipping treatments. However, the moderately grazed plants had significantly $35 \%$ fewer new shoots than the ungrazed plants.

\section{Plants and Grasshopper Development in the Field}

Average weekly culm heights for western wheatgrass and needleand-thread grass in relation to grasshopper development are shown in Figure 2. The later instars and the adult stage of the grasshoppers developed after the active growth period of the cool-

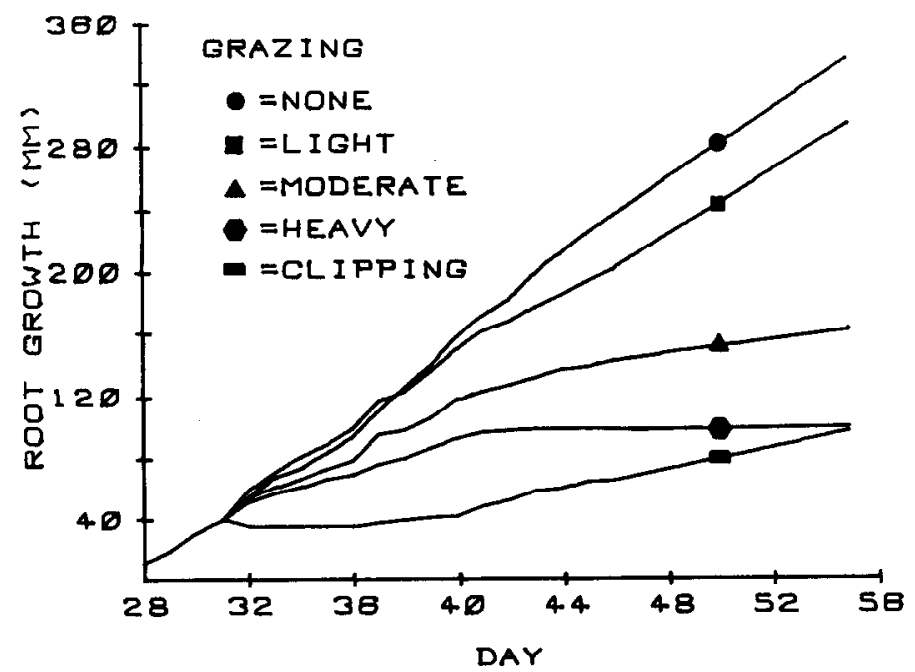

Fig. 1. Maximum depth of root penetration of western wheatgrass before, during, and after grazing and clipping treatments.

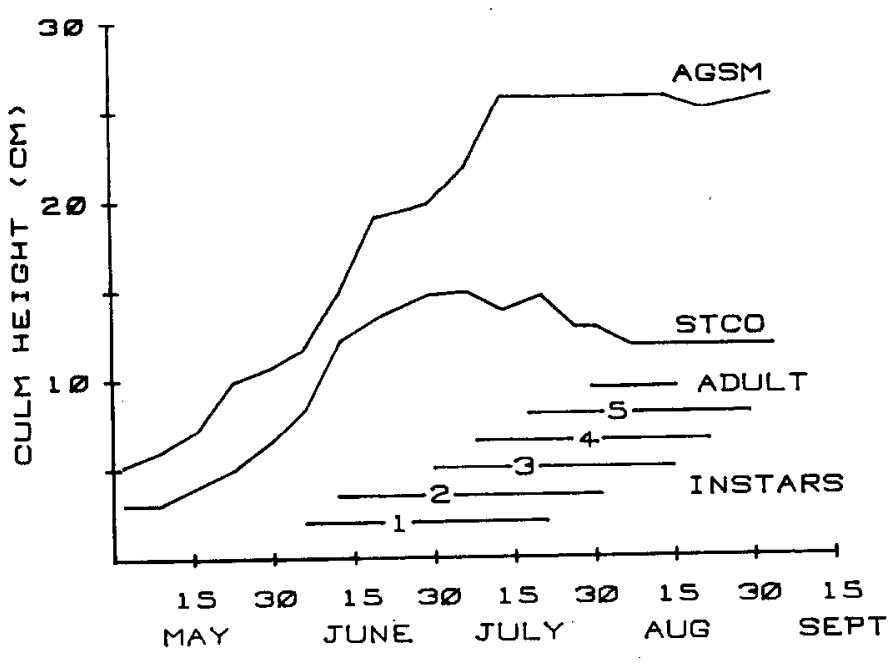

Fig. 2. Average culm height of western wheatgrass (AGSM) and needleand-thread grass (STCO) in relation to grasshopper development.

season grasses. Most of the adult portion of the grasshopper life span occurred from the latter part of July through September. An exception was Psoloessa delicatula (Scudder), which overwinters in the nymphal stage. This grasshopper and a few other species that overwinter as nymphs could possibly be detrimental to early coolseason grasses. However, such species usually do not occur in high numbers.

The year under consideration was atypically cool with high precipitation. In general, cool-moist spring weather prolongs the time spent by grasshoppers in the nymphal stage.

Measurements of root elongation in the field were highly variable for both western wheatgrass and needle-and-thread grass. The roots would grow against the glass for a short period of time and then die back or turn away from the glass. Weekly measurements showed an average daily root growth of $10 \mathrm{~mm}$ per day.

During mid-July, the roots of both grass species nearly stopped growing against the glass panes at the time of anthesis. Only occasional elongation was observed after this date. No estimation of early spring (May) root growth was made; however, some rhizome activity was noted during September.

\section{Discussion}

It is apparent that defoliation of plants by grasshoppers does have an adverse affect on plant growth and development under the conditions of the tests. Previous studies where plants were clipped at different frequencies and at different heights showed that yield was reduced (Holscher 1945, White 1973, Buwai and Trlica 1977b), and the rate of root growth decreased (Bokhari and Singh 1974). Generally, the more frequent and severe the removal of herbage, the greater the depression in yield. However, some studies show that defoliation does not drastically affect affect plant growth. For example, Trlica et al. (1977) evaluated western wheatgrass plants 14 to 26 months after the plants were heavily defoliated $(90 \%$ of foilage removed) during each of four different phenological stages and found all plants had herbage yields similar to the control plants. Buwai and Trlica (1977a) also reported that root weights of clipped western wheatgrass plants were only slightly less than those of the undefoliated plants.

Grasshoppers and rangeland plants have evolved together in the rangeland ecosystem, thus it seems that light or moderate grazing by grasshoppers would probably not be detrimental to most plant species. However, high grasshoper numbers reduce available forage and may destroy entire plants, especially during periods of drought (Nerney and Hamilton 1969). Grasshopper grazing is unique and different than livestock grazing in that forage is removed at random heights on each plant, grazing pressure occurs daily from hatching till death, there is no trampling affect as with 
livestock, and selective grazing on preferred plants may lead to plant mortality in one grazing season (Newton and Esselbaugh 1952, Mitchell and Pfadt 1974, White 1974). Many factors are certainly involved in determining the affect of grasshopper grazing on rangeland plants and additional studies are indeed justified to further explain this process.

\section{Summary}

Both greenhouse and field data of needle-and-thread grass indicated that as grasshöpper grazing intensity increased, total root weight decreased. Heavy grazing $(80 \%$ removal of top growth of western wheatgrass) for a 16-day period was the most detrimental of all treatments studied. Observation and data showed that moderate rates of grazing ( $50 \%$ removal of top growth) and a one-time clipping (to a $2.5-\mathrm{cm}$ level, $90 \%$ ) reduced root growth 70 and $60 \%$, respectively. As grasshopper grazing intensity increased on western wheatgrass there was: (1) a reduction in total root, crown, and rhizome weight, (2) a reduction in maximum depth of root penetration, and (3) a reduction in the number of new shoots produced. Field observations indicated that most grasshopper defoliation occurred after the active growth period of needle-and-thread and western wheatgrass, thus the influence of this grazing is probably less drastic than if it occurred during the period of active growth.

Most range managers seek to obtain maximum livestock production without overgrazing critical rangeland plants but often neglect the effect of other grazing herbivores, such as grasshoppers which may increase unexpectedly in any year. Results of this study indicate that grasshoppers should also be managed, or severe overgrazing may occur and plant reserves seriously depleted. In general, rangeland grasshopper control is carried out to reduce forage losses and prevent movement of grasshoppers into crops.
An additional objective might be to increase plant vigor and reduce range deterioration.

\section{Literature Cited}

Bokhari, U.G., and J.S. Singh. 1974. Effects of temperature and clipping on growth, carbohydrate reserves, and root exudation of western wheatgrass in hydroponic culture. Crop Sci. 14:790-794.

Buwai, M., and M.J. Trlica. 1977a. Defoliation effects on root weights and total nonstructural carbohydrates of blue grama and western wheatgrass. Crop Sci. 17:15-17.

Buwai, M., and M.J. Trlica. 1977b. Multiple defoliation effects on herbage yield, vigor, and total nonstructural carbohydrates of five range species. J. Range Manage. 30:164-171.

Hewitt, G.B. 1977. Review of forage losses caused by rangeland grasshoppers. U.S. Dep. Agr., Agr. Res. Serv., Misc. Pub. No. 1348, 22 p.

Holscher, C.E. 1945. The effects of clipping bluestem wheatgrass and blue grama at different heights and frequency. Ecology 26:148-156.

Mazuranich, P.C. 1975. Construction of a metal framed cage for studies with grasshoppers. Acrida 4:151-154.

Mitchell, J.E., and R.E. Pfadt. 1974. A role of grasshoppers in a shortgrass prairie ecosystem. Envir. Entomol. 3:358-360.

Nerney, N.J., and A.G. Hamilton. 1969. Effects of rainfall on range forage and populations of grasshoppers, San Carlos Apache Indian Reservation, Arizona. J. Econ. Entomol. 62:329-333.

Newton, R.C., and C.O. Esselbaugh. 1952. Damage to range vegetation in eastern Wyoming. U.S. Dep. Agr. Spec. Rep. No. D 24.

Trlica, M.J., M. Buwai, and J.W. Menke. 1977. Effects of rest following defoliations on the recovery of several range species. J. Range Manage. 30:21-27.

White, E.G. 1974. Grazing pressures of grasshoppers in an alpine tussock grassland. N.Z.J. Agr. Res. 17:357-372.

White, LM. 1973. Carbohydrate reserves of grasses. A Review. J. Range Manage. 26:13-17.

\section{New Editor for JRM}

Replacing Dr. Rex D. Pieper as editor of the Journal of Range Management is Patricia G. Smith. Dr. Smith is currently Production Editor of the Journal and has worked with SRM publications since 1972.

Other organizational changes are taking place. Editorial Board members will now serve as associate editors, who will direct the review process and select manuscripts for publication in their area of special expertise. The associate editors will serve for a 3-year term. Current associate editors are: Gary Frasier, Henry Mayland, John Menke, Kieth Severson, Stephen Sharrow, Marvin Shoop, Dan Uresk, Phillip Urness, Steve Waller, Bruce Welch, Earl Willard, and Karl Wood. To ensure continuity, terms overlap as before.

Under the new process, manuscripts will be channeled through the Denver $J R M$ office (see Instructions for Authors on the inside back cover) to the appropriate associate editor. During the review process, the associate editor will correspond with authors concerning the manuscript. The associate editors will return accepted manuscripts to the editor, who will make up the issues, direct production, and take up correspondence with authors at this point.

The new structure is designed to share the increasing burden of the editorship while providing a suitable review process.

Contributing to the professional quality of the Journal of Range Management is a significant service to both the Society for Range Management and the profession. Individuals interested in scrving as reviewers and/or eventually as associate editors are invited to submit their names and a brief description of their areas of competence to the Editor, Society for Range Management, 2760 West Fifth Avenue, Denver, Colorado 80204.

The Society and the profession are grateful to Dr. Pieper, who served as editor since May, 1977-no small achievement for a range scientist also carrying on full-time work responsibilities. 